\title{
Chapter 14 \\ Article 9: The Right Not to Be Separated from Parents
}

\author{
Christian Whalen
}

1. States Parties shall ensure that a child shall not be separated from his or her parents against their will, except when competent authorities subject to judicial review determine, in accordance with applicable law and procedures, that such separation is necessary for the best interests of the child. Such determination may be necessary in a particular case such as one involving abuse or neglect of the child by the parents, or one where the parents are living separately and a decision must be made as to the child's place of residence.

2. In any proceedings pursuant to paragraph 1 of the present article, all interested parties shall be given an opportunity to participate in the proceedings and make their views known.

3. States Parties shall respect the right of the child who is separated from one or both parents to maintain personal relations and direct contact with both parents on a regular basis, except if it is contrary to the child's best interests.

4. Where such separation results from any action initiated by a State Party, such as the detention, imprisonment, exile, deportation or death (including death arising from any cause while the person is in the custody of the State) of one or both parents or of the child, that State Party shall, upon request, provide the parents, the child or, if appropriate, another member of the family with the essential information concerning the whereabouts of the absent member(s) of the family unless the provision of the information

(continued)

C. Whalen $(\bowtie)$

Office of the Child, Youth and Seniors Advocate, Fredericton, NB, Canada

e-mail: Christian.Whalen@gnb.ca

Z. Vaghri et al. (eds.), Monitoring State Compliance with the UN Convention

on the Rights of the Child, Children's Well-Being: Indicators and Research 25,

https://doi.org/10.1007/978-3-030-84647-3_14 
would be detrimental to the well-being of the child. States Parties shall further ensure that the submission of such a request shall of itself entail no adverse consequences for the person(s) concerned.

\section{What Did Children Say?}

'Are children's voices being heard when separated from parents?' (Latin America/Caribbean)

'Government officials should personally take children to visit parents or give them the means of contact and communication with parent.' (Africa)

'When a child who lives with another person asides his parent is allowed to see/call them without any restrictions.' (Africa)

'The government should make and enforce rules and regulations that guide relatives/guardians in the care of their children.' (Africa)

\section{Overview}

Article 9 of the Convention is the first of a group of Articles, 9, 10, and 11, that are specific to children and which have no exact counterpart in general human rights treaties, outside of the regional child rights context in Africa. ${ }^{1}$ The right not to be separated from parents, the right to leave and enter countries for family reunification, and the obligation on States Parties to take specific measures to combat the illicit transfer and non-return of children from abroad, work together to protect the child's right to secure family attachment and relationships. These rights therefore are to be read closely and in conjunction with one another and with other rights in the Convention that deal specifically with the child's family situation, including Articles 3, 5, 7, 16 18, 20, 21, and 27 (Tobin \& Cashmore, 2019, pp. 308-310).

Article 9 serves as a gateway to these specific rights of children and sets out two main principles: children must not be separated from their parents unless the separation is necessary in their best interests, and the child and parents should not be separated without due process in any circumstance including child protection or child custody matters (Nowak, 2005, p. 121; UNICEF, 2007, p. 186). Article 9 also protects the child's right to maintain contact with both parents, unless their best interests indicate otherwise, and places an obligation on States Parties to keep parents and children informed of any state action that might impinge upon this right.

The Travaux Préparatoires show that Article 9 grew out of a proposal for an early draft of Article 10, and which focused on the child's right to a residence. Through the

\footnotetext{
${ }^{1}$ See Article 19 of the African Charter on the Rights and Welfare of the Child (African Union, 1981), adopted in 1990 with a provision on Parent Care and Protection which tracks the language of UNCRC Article 9 fairly closely.
} 
several years of the Convention's drafting, the child's right to not be separated from their parents emerged as the central theme and this became Article 9 (Detrick et al., 1992). The focus of Article 9 is on separation from parents within the domestic context, while Articles 10 and 11 deal with the distinct elements of separation which can occur across international borders, respectively entering or leaving countries for family reunification and illicit transfer and non-return of children abroad (Detrick et al., 1992, p. 22).

\section{General Principles}

Article 2 Equality and non-discrimination rights are particularly relevant in applying Article 9 since minority and vulnerable child and youth populations, such as LBGTQ youth, disabled children, refugee children, street endangered children, children in poverty, drug-endangered youth, and children in situations of armed conflict are inherently at risk of being separated from their parents and without adequate due process (UN General Assembly, 2010, para. 9). The Committee has often warned against overrepresentation of indigenous children and minority children in systems of state care or juvenile detention (2012, paras. 53-58, 85-86).

Article 3 The child's best interests must be the determining consideration in all decisions affecting any separation from his or her parents. Article 9 takes the General Principle of Article 3 a step further, beyond the standard of primary consideration, and ensures that is upheld as the determining factor in decisions involving a separation, involving efforts to maintain contact with both parents, or with the child's extended family, or to be kept informed of state reasons requiring a separation of parent and child.

Article 6 The child's right to life, survival, and maximum development also relates closely to Article 9 rights, given the parents' primary role as caregivers. This principle emphasises the need to support parents in the assumption of their parental obligations, as the Committee has mentioned that children must not be removed from their parents merely because of the family's impoverished condition (UNICEF, 2007, p. 123; 2006a, paras. 37-38, 2006b, para. 30). ${ }^{2}$

Article 12 Paragraph 2 of Article 9 expressly reaffirms the Article 12 principle in relation to a child's right to express their views and have them considered in decisions relating to any matter arising from a separation from their parents, but the paragraph extends the same right to parents and indeed 'all interested parties.'

\footnotetext{
${ }^{2}$ Compare Guidelines for Alternative Care (UN General Assembly, 2010, para. 15)
} 


\section{Articles Related to or Linked to Article 9}

Article 5 is a corresponding responsibility on parents to provide guidance and direction to their children.

Article 7 proclaims the child's right to know and to be cared for by their parents.

Article 8 protects the right to preservation of identity, including family relations and to be reconnected with family if these relations are disrupted.

Article 10 concerns the right to leave or enter one's country or one's parents for family reunification.

Article 11 recognises the child's right to be protected from international abduction.

Article 16 considers the child's right to privacy and the inviolability of his or her family life.

Article 18 recognises the common responsibilities of both parents with appropriate State supports for the upbringing and development of the child.

Article 20 concerns the child's right to alternative care if deprived of their family.

Article 21 covers the child's rights in relation to adoption.

Article 22 recognises the rights of refugee children and specifically their right to be reunited with family when separated.

Article 25 covers the child's right to periodic review of treatment when placed by the State away from their family.

Article 27 attributes the child's right to a decent standard of living, including the right to recover payment of alimony from parents abroad.

Article 35 affirms the child's right to be protected from abduction, sale, or trafficking.

Article 37 concerns the rights of children deprived of liberty to maintain contact with family.

\section{Relevant Instruments}

UN Universal Declaration of Human Rights (1948), Article 16, proclaims the right of men and women to marry and found a family, and establishes the family as the natural and fundamental element of society.

UN Declaration of the Rights of the Child (1959), Article 6, protects the child's right to 'grow up in the care and under the responsibility of his parents.'

International Covenant on Civil and Political Rights (1966), Articles 17, 23 and 24 .

International Covenant on Economic, Social and Cultural Rights (1966), Article 10.

UN Convention on the Rights of Persons with Disabilities (2006), Article 23(4), protects the parent-child relationship in relation to both disabled parents and disabled children. 
UN Guidelines for the Alternative Care of Children (2009)

European Convention on Human Rights (1950), Article 8, Right to Privacy and Family Life

American Convention on Human Rights 'Pact of San Jose, Costa Rica' (B-32) (1978), Article 11, privacy and family life, Article 12, freedom of conscience and right of parents to provide for the religious or moral education of their children in accordance with their own convictions, Articles 17-20 rights of the family, right to a name, rights of the child and right to a nationality.

African Charter on Human and Peoples' Rights (1981), Article 18, rights of the family, Article 27 and 29 Duty to family and society and duty to preserve harmonious development of the family.

African Charter on the Rights and Welfare of the Child (1990), Articles 18, 19, 25 and 30.

\section{Attributes}

\section{Attribute One: No Separation from Parents Unless Necessary for the Child's Best Interests}

The first attribute insists upon the child's right to be with their parents unless a separation is necessary in the child's best interest. The language of the provision speaks to the crucial importance of the bond between parent and child because the test is one of necessity and the determining criterion is the child's best interests. Governments may invoke many good reasons to detain a parent and force a separation between a parent and child, but the Convention requires States Parties to consider the child's best interests and determine whether separation is necessary on the basis of that criterion.

Article 9(1) gives two examples of when separation is necessary, in child protection matters and upon divorce or separation of the parents, but these are merely illustrative. Other examples of situations where separations occur and where the standards of necessity and best interests should be applied include situations where children are hospitalised for lengthy periods (UN Committee on the Rights of the Child, 2004a, paras. 51, 52), where parents are detained in prison, ${ }^{3}$ where children are detained in prison (UN General Assembly, 1991, paras. 59-62), where parents work abroad (UN Committee on the Rights of the Child, 1994, paras. $16,33,2002 \mathrm{a}$, paras. 30, 31), where children are affected by or involved in armed

\footnotetext{
${ }^{3}$ This includes the concern about detaining infants with their parents sentenced to serve time in prison: See Concluding Observations to Nepal (2005a, paras. 51-52); it also includes the creation of sentencing practices that allow sentences given to parents to be served in community and providing alternative care for children of detained adults while maintaining regular parent-child contact. See Concluding Observations to Mexico (2006c, para. 40) and UN Guidelines on Alternative Care of Children (UN General Assembly, 2010, para. 48)
} 
conflict (UN Secretary General, 2016, paras. 9, 16, 18, 20), as a consequence of immigration, deportation and refugee matters (UN Committee on the Rights of the Child, 2005b, para. 50), or due to traditions or customs which force separation or child abandonment (such as unwed mothers, sex selection, intersex births, and birth deformities) (UNICEF, 2007, p. 127).

\section{Attribute Two: No Separation from Parents Without Due Process Before Competent Authorities}

Article 9 focusses on the due process requirements introduced by the words 'except when competent authorities subject to judicial review determine, in accordance with applicable law and procedure' in paragraph 1 . The requirement in paragraph 2 , that all interested parties be given the opportunity to participate and make their views known in these determinations, is a further aspect of this attribute of due process (UNICEF, 2007, p. 127). This includes, of course, the child's participation whose right to not be forcibly separated from his or her parents is conditioned by the terms 'against their will.' If the child is seeking emancipation or separation from one or both parents the entire proceedings may take a different course, which underscores the importance of the child's participation. The concluding observations provide guidance with respect to who is a competent authority (UN Committee on the Rights of the Child, 2002a, paras. 38, 39, 2004b, paras. 30, 31), how judicial review requires elements of fairness and due process (UNICEF, 2007, p. 128; UN Committee on the Rights of the Child, 2002b, paras. 36, 37, 2005c, para. 26, 2005d, para. 37 ), and how to elicit the views of the child (UN Committee on the Rights of the Child, 2003, paras. 38, 39, 2005e, paras. 23, 24). The Article also requires State Parties to enact clear laws and procedures to regulate such determinations. Guidance as to the fairness requirements of such laws can be found in the Beijing Rules as well as in the Guidelines for the Alternative Care of Children (UN General Assembly, 1985, Rule 3.2, 2010, paras. 9, 32, 48, 52). Any breach of these fairness requirements may be raised to question the legitimacy of a forced separation of child and parent and may constitute a violation of the child's rights under Article 9, which are both substantive and procedural.

\section{Attribute Three: Right to Maintain Relations and Regular Contact with Both Parents, if Separated}

The third attribute of Article 9 is set out in paragraph 3 and guarantees the child's right to maintain personal relations and direct contact with both parents on a regular basis if separated, unless doing so would be contrary to his or her best interests. States Parties laws should not privilege contact with one parent at the expense of the 
other, and contact and maintenance of relations with non-custodial parents is protected by the Convention (UN Committee on the Rights of the Child, 2004c, paras. 39, 40). Civil administrations should take special measures to promote relations and personal contact with parents by all appropriate means, including visitation, with or without supervision, and joint custody but also through telecommunications and social media. Children separated from their parents internationally also have a right to family reunification even when reunification cannot occur in the country of origin (UN Committee on the Rights of the Child, 2005f, paras. 81-90).

\section{Attribute Four: Right to Be Informed of Whereabouts of Child or Parent if Detained}

The fourth and final attribute of Article 9 is set out in paragraph 4 and elaborates the right of family members, including both children and parents, but also components of the extended family, to be informed of the whereabouts of a child or parent who is missing or detained as a result of some state action. Article 9 guards against the danger that children be kept unaware of life changing circumstances in their parents' lives no matter how harsh the truths (UN Committee on the Rights of the Child, 2004d, paras. 42, 43). Parents and children have a right to be informed of each other's situations even when they are apart. Article 9 only proposes minimum rules to guard against state impunity in the face of forced separations of parents and children (UNICEF, 2007, p. 131). Other international standards help complete State Party obligations in this regard. For instance, where children are detained, they have a right to be informed at the earliest possible time of any death or serious illness or injury of their family members (UN General Assembly, 1991, para. 58).

\section{References}

African Union. (1981). African (Banjul) charter on human and peoples' rights (No. CAB/LEG/67/ 3 rev.5, 21 ILM). https://www.achpr.org/legalinstruments/detail?id=49

Detrick, S., Doek, J. E., \& Cantwell, N. (1992). The United Nations Convention on the Rights of the Child: A guide to the "Travaux Préparatoires." Martinus Nijhoff Publishers.

Nowak, M. (2005). U.N. covenant on civil and political rights: CCPR commentary. N.P. Engel.

Tobin, J., \& Cashmore, J. (2019). Article 9: The rights not to be separated from parents. In J. Tobin (Ed.), The UN Convention on the Rights of the Child: A commentary (pp. 307-342). Oxford University Press.

UN Committee on the Rights of the Child. (1994). Concluding observations: Sri Lanka, June 21, 1994, CRC/C/15/Add.40. Retrieved November 6, 2020, from https://digitallibrary.un.org/ record/191817? $\mathrm{ln}=\mathrm{en}$

UN Committee on the Rights of the Child. (2002a). Concluding observations: St. Vincent and the Grenadines, June 13, 2002, CRC/C/15/Add.184. Retrieved November 6, 2020, from https:// digitallibrary.un.org/record/473488? $\mathrm{ln}=\mathrm{en}$ 
UN Committee on the Rights of the Child. (2002b). Concluding observations: Lebanon, March 21, 2002, CRC/C/15/Add.169. Retrieved October 11, 2020, from https://digitallibrary.un.org/ record $/ 467259 ? \mathrm{ln}=\mathrm{en}$

UN Committee on the Rights of the Child. (2003). Concluding observations: Haiti, March 18, 2003, CRC/C/15/Add.202. Retrieved October 11, 2020, from https://digitallibrary.un.org/ record $/ 497803 ? \mathrm{ln}=$ en

UN Committee on the Rights of the Child. (2004a). Concluding observations: Croatia, November 3 2004, CRC/C/15/Add.243. Retrieved October 11, 2020, from https://digitallibrary.un.org/ record $/ 557375 ? \mathrm{ln}=\mathrm{en}$

UN Committee on the Rights of the Child. (2004b). Concluding observations: Slovenia, February 26, 2004, CRC/C/15/Add.230. Retrieved October 12, 2020, from https://digitallibrary.un.org/ record $/ 530811 ? \mathrm{ln}=\mathrm{en}$

UN Committee on the Rights of the Child. (2004c). Concluding observations: Antigua and Barbuda, November 3, 2004, CRC/C/15/Add.247. UN. Retrieved November 6, 2020, from http://digitallibrary.un.org/record/557388

UN Committee on the Rights of the Child. (2004d). Concluding observations: Korea, July 1, 2004, $C R C / C / 15 / A d d .239$. UN. Retrieved November 6, 2020, from http://digitallibrary.un.org/record/ 536573

UN Committee on the Rights of the Child. (2005a). Concluding observations: Nepal, September 1, 2005, CRC/C/15/Add.261. Retrieved October 11, 2020, from https://digitallibrary.un.org/ record $/ 569886 ? \mathrm{ln}=\mathrm{en}$

UN Committee on the Rights of the Child. (2005b). Concluding observations: China, November 24, 2005, CRC/C/CHN/CO/2. Retrieved October 24, 2020, from https://digitallibrary.un.org/ record $/ 575653 ? \mathrm{ln}=\mathrm{en}$

UN Committee on the Rights of the Child. (2005c). Concluding observations: Finland, October 20, 2005, CRC/C/15/Add.272. UN. Retrieved November 6, 2020, from http://digitallibrary.un. org/record/569953

UN Committee on the Rights of the Child. (2005d). Concluding observations: Nicaragua, September 21, 2005, CRC/C/15/Add.265. Retrieved October 11, 2020, from https:// digitallibrary.un.org/record/570466? $\mathrm{ln}=\mathrm{en}$

UN Committee on the Rights of the Child. (2005e). Concluding observations: Sweden, March 30, 2005, CRC/C/15/Add.248. Retrieved October 11, 2020, from https://digitallibrary.un.org/ record $/ 557390 ? \mathrm{ln}=\mathrm{en}$

UN Committee on the Rights of the Child. (2005f). General Comment No. 6 (2005) Treatment of Unaccompanied and Separated Children Outside their Country of Origin, September 1, 2005, $C R C / G C / 2005 / 6$. Retrieved October 12, 2020, from https://digitallibrary.un.org/record/566055? $\ln =\mathrm{en}$

UN Committee on the Rights of the Child. (2006a). Concluding observations: Azerbaijan, March 17, 2006, CRC/C/AZE/CO/2. Retrieved October 11, 2020, https://digitallibrary.un.org/record/ $575654 ? \ln =\mathrm{en}$

UN Committee on the Rights of the Child. (2006b). Concluding observations: Hungary, March 17, 2006, CRC/C/HUN/CO/2. Retrieved October 11, 2020, from https://digitallibrary.un.org/ record $/ 575773 ? \mathrm{ln}=\mathrm{en}$

UN Committee on the Rights of the Child. (2006c). Concluding observations: Mexico, June 8, 2006, $C R C / C / M E X / C O / 3$. https://digitallibrary.un.org/record/582289? ln=en

UN Committee on the Rights of the Child. (2012). Concluding observations: Canada, December 6, 2012, CRC/C/CAN/CO/3-4. Retrieved October 11, 2020, from https://digitallibrary.un.org/ record $/ 739319 ? \mathrm{ln}=\mathrm{en}$

UN General Assembly. (1985). United Nations standard minimum rules for the administration of juvenile justice ("The Beijing Rules"), 1985, A/RES/40/33. Retrieved November 6, 2020, from http://digitallibrary.un.org/record/120958 
UN General Assembly. (1991). United Nations rules for the protection of juveniles deprived of their liberty, 1990, A/RES/45/113 (The Havana Rules). UN. Retrieved October 26, 2020, from http:// digitallibrary.un.org/record/105555

UN General Assembly. (2010). Guidelines for the alternative care of children, 2010, A/RES/64/ 142. https://digitallibrary.un.org/record/673583? $\mathrm{ln}=\mathrm{en}$

UN Secretary General. (2016). Children and armed conflict: Report of the Secretary-General, A/70/ 836 S/2016/360. Retrieved November 6, 2020, from http://digitallibrary.un.org/record/830518

UNICEF. (2007). Implementation handbook for the convention on the rights of the child (3rd ed.) UNICEF. Retrieved April 19, 2020, from https://www.unicef.org/publications/index_43110. html

Open Access This chapter is licensed under the terms of the Creative Commons Attribution 4.0 International License (http://creativecommons.org/licenses/by/4.0/), which permits use, sharing, adaptation, distribution and reproduction in any medium or format, as long as you give appropriate credit to the original author(s) and the source, provide a link to the Creative Commons license and indicate if changes were made.

The images or other third party material in this chapter are included in the chapter's Creative Commons license, unless indicated otherwise in a credit line to the material. If material is not included in the chapter's Creative Commons license and your intended use is not permitted by statutory regulation or exceeds the permitted use, you will need to obtain permission directly from the copyright holder. 